\title{
PERHITUNGAN VALUE AT RISK (VAR) DENGAN METODE HISTORIS DAN MONTE CARLO PADA SAHAM SUB SEKTOR ROKOK
}

\author{
Achmad Dimas Adrianto \\ dimas.adrianto28@gmail.com \\ Muhammad Azhari \\ Khairunnisa \\ Fakultas Ekonomi dan Bisnis, Universitas Telkom
}

diterima: 12/05/2017; direvisi: 07/08/2017; diterbitkan: 24/2/2018

\begin{abstract}
The government's policy, the Indonesian Ulema Council's (MUI) fatwa, the rise of cigarette issues and anti-smoking campaigns have been a major challenge for the tobacco industry in managing risks. Through this research, the issues will be measured by VaR to know the risk of the company's shares of cigarette sub sector by using time series data and analyzed by using the simulation method of Historis and Monte Carlo. The results showed the VaR value of GGRM and HMSP stock with the historical method is 3.28 and 2.54\%. While the value of VaR shares GGRM and HMSP with Monte Carlo method is $3.52 \%$ and $3.14 \%$. Monte Carlo simulation gives greater result than Historical Simulation, because Monte Carlo simulation do iteration repeatedly by involving random number generation and many synthesize the data so that sample data becomes more which makes the calculation is bigger.
\end{abstract}

Keywords : value at risk; hisorical simulation; Monte Carlo simulation; risk; return

\begin{abstract}
Abstrak
Kebijakan pemerintah, fatwa Majelis Ulama Indonesia(MUI), munculnya isu rokok dan gencarnya kampanye anti rokok menjadi tantangan besar industri rokok dalam mengelola risiko. Melalui penelitian ini akan dilakukan pengukuran VaR untuk mengetahui risiko saham perusahaan sub sektor rokok dengan menggunakan data time series dan dianalisis dengan menggunakan metode simulasi Historis dan Monte Carlo. Hasil penelitian menunjukan nilai VaR saham GGRM dan HMSP dengan metode Historis adalah 3,28 dan 2,54\%. Sedangkan nilai VaR saham GGRM dan HMSP dengan metode Monte Carlo adalah 3,52\% dan 3,14\%. Simulasi Monte Carlo memberikan hasil yang lebih besar dibandingkan Simulasi Historis, karena simulasi Monte Carlo melakukan iterasi yang berulang ulang dengan mengikutsertakan pembangkitan bilangan acak dan banyak mensintesiskan data sehingga sample data menjadi lebih banyak yang membuat perhitungan semakin besar.
\end{abstract}

Kata Kunci : value at risk; simulasi historis; simulasi Monte Carlo; risk; return 


\section{PENDAHULUAN}

Industri sub sektor rokok merupakan bagian dari sektor Barang Konsumsi. Dalam sektor barang konsumsi (consumer goods) terdapat empat sub sektor lainya yaitu food and beverages (makanan dan minuman), pharaceuticals (kimia), cosmetic and household (kosmetik), dan houseware (perlengkapan rumah tangga).

Saat ini terdapat empat perusahaan rokok yang terdaftar di Bursa Efek Indonesia (Tabel 1) dan data keuntungan ditunjukkan pada Gambar 1.

Tabel 1. Perusahaan Rokok yang terdaftar di BEI

\begin{tabular}{cllc}
\hline No & Kode Saham & \multicolumn{1}{c}{ Nama Emiten } & \multicolumn{1}{c}{ Tanggal IPO } \\
\hline 1 & GGRM & Gudang Garam Tbk. & 27 Agustus 1990 \\
2 & HMSP & $\begin{array}{l}\text { Handjaya Mandala } \\
\text { Sampoerna Tbk. }\end{array}$ & 15 Agustus 1990 \\
& & $\begin{array}{l}\text { Wismilak Inti Makmur } \\
\text { 18k. }\end{array}$ & 18 Desember 2012 \\
& WIIM & Tbk. & \\
4 & RMBA & Bentoel Internasional & 5 Maret 1990 \\
& & Investama Tbk & \\
\hline
\end{tabular}

Sumber: www.sahamoke.com

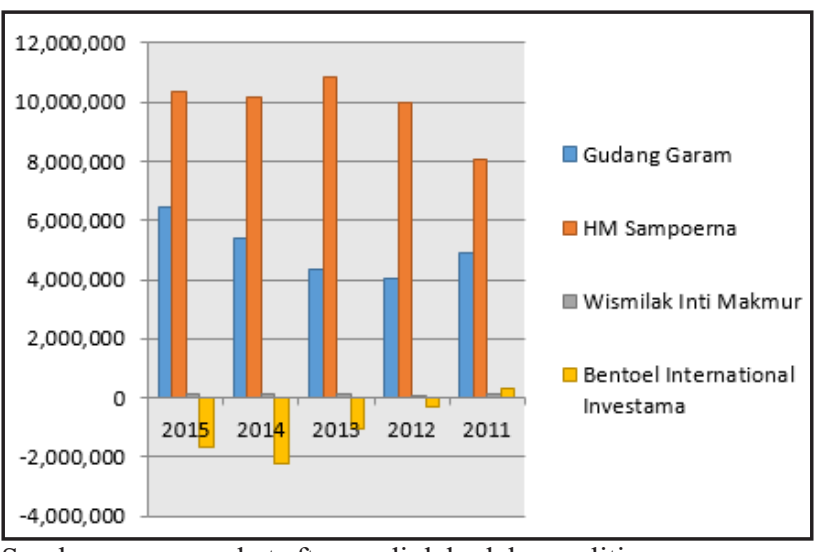

Sumber: www.markets.ft.com diolah oleh peneliti

Gambar 1. Net Profit Perusahaan rokok yang terdaftar di BEI $2011-2015$

Keuntungan perusahaan rokok mengalami fluktuasi sepanjang lima tahun. Hanya Bentoel International Investama saja yang terus mengalami penurunan dan satu-satunya perusahaan rokok yang mengalami kerugian. Wismilak Inti Makmur keuntunganya tidak selalu meningkat, tetapi masih stabil. Sedangkan Gudang Garam dan HM Sampoerna adalah dua perusahaan yang paling mengalami fluktuasi pada lima tahun tersebut, maka saham perusahaan rokok yang akan diteliti adalah Gudang Garam dan HM Sampoerna.

Investasi adalah penanaman sejumlah uang untuk periode tertentu untuk menerima pembayaran di masa depan yang akan mengkompensasikan kerugian investor untuk (1) waktu dana yang telah diinvestasikan, (2) adanya tingkat inflasi di masa yang akan datang, (3) ketidakpastian di masa depan (Brown dan Reilly, 2011:4).

Menurut Setianto (2011) perusahaan rokok terus tumbuh dan memberikan kinerja yang bagus di Indonesia. Perusahaaan rokok memiliki kinerja yang sangat bagus, pertumbuhan laba naik terus dan menekan atau mempertahankan investasi modal sehingga tidak terjadi kenaikan.

Pada dasarnya setiap investasi yang dilakukan dengan tujuan memperoleh sejumlah keuntungan di masa yang akan datang (Tandelilin, 2010: 2). Pada kenyataannya beberapa investasi masih belum dapat memperoleh hasil yang menguntungkan, justru investasi tersebut mengalami kerugian, hal ini dikarenakan setiap investasi memiliki potensi risiko.

Seiring banyak munculnya kebijakan pemerintah, keluarnya fatwa Majelis Ulama Indonesia (MUI) mengenai rokok, dan gencarnya kampanye anti rokok menjadi tantangan besar industri rokok maupun para investornya dalam mengelola risiko yang akan terjadi dimasa mendatang. Pemerintah menyadari bahwa rokok merugikan kesehatan masyarakat, sehingga harus dibatasi. Hal ini sejalan dengan prinsip pengenaan cukai yaitu untuk mengendalikan konsumsi dan mengawasi peredaran. Salah satu tindakan pemerintah dalam mengendalikan konsumsi dan mengawasi peredaran ialah pada 21 September 2015 pemerintah menerbitkan peraturan menteri keuangan Republik Indonesia Nomor 174/PMK.03/2015 tentang tatacara perhitungan dan pemungutan pajak pertambahan nilai atas penyerahan hasil tembakau yang membuat tarif Pajak Pertambahan Nilai (PPN) rokok naik menjadi 8,7\%.

Dari paparan di atas, risiko yang paling banyak dihadapi industri rokok adalah risiko tidak sistematis dan risiko industri. Risiko tidak sistematis (unsystematic risk) adalah risiko hanya membawa dampak pada perusahaan terkait saja (Fahmi, 2012: 189). Sedangkan risiko industri biasanya dipengaruhi oleh tiga faktor, yaitu teknologi, hukum dan komoditas (Damodaran, 2010: 11).

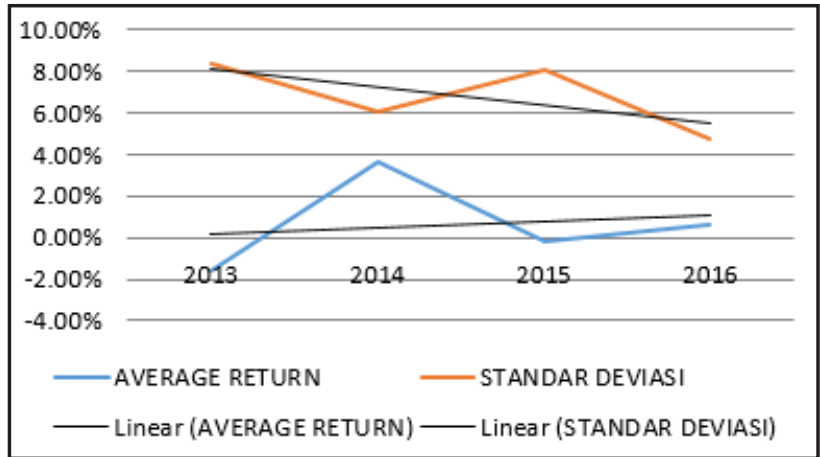

Sumber: www.fincance.yahoo.com data di olah oleh peneliti

Gambar 2. Pergerakan average return dan standar deviasi Gudang Garam 2013-2016 


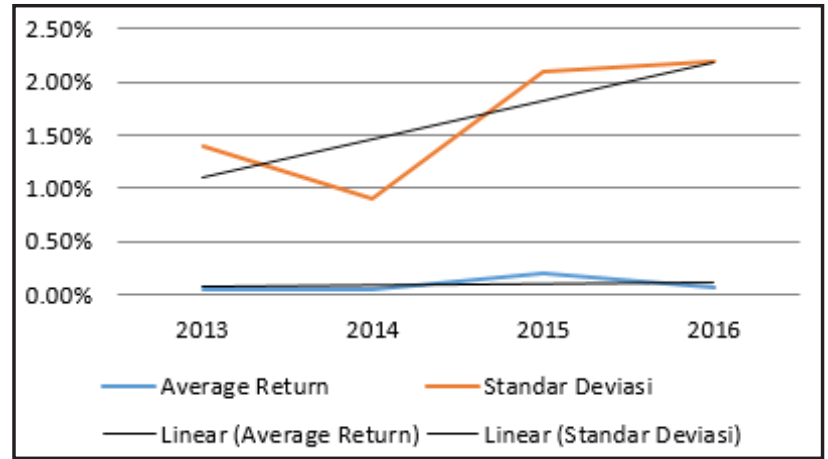

Sumber: www.fincance.yahoo.com data di olah oleh peneliti

Gambar 3. Pergerakan average return dan standar deviasi HM Sampoerna 2013-2016

HM Sampoerna dan Gudang Garam memiliki kualitas fluktuatif yang cukup tinggi, baik standar deviasi maupun average return (Gambar 2 dan 3). Dengan adanya fluktuasi maka investor harus menghitung nilai risiko pada kedua saham tersebut. Bodie (2014:10) menyebutkan apabila investor ingin memiliki tingkat return yang tinggi maka investor juga harus menerima risiko investasi yang lebih tinggi.

Pengukuran risiko merupakan aspek yang sangat penting dalam analisis keuangan yang berkaitan dengan investasi dana yang besar, hal ini berkaitan dengan besarnya dana yang diinvestasikan dan hal yang paling utama diperhatikan setiap calon investor adalah menentukan asset beresiko mana yang akan di beli. Menurut (Jorion 2007 : 244) Value at Risk (VaR) merupakan metode perhitungan market risk untuk menentukan risiko kerugian maksimum yang dapat terjadi pada suatu portfolio, baik single-instrument ataupun multi-instruments, pada confidence level tertentu, selama holding period tertentu, dan dalam kondisi pasar yang normal.

Perhitungan ini akan sangat membantu investor dalam mengambil keputusan untuk menginvestasikan sejumlah dana. Oleh sebab itu, pengukuran risiko perlu dilakukan agar risiko berada dalam tingkatan yang terkendali sehingga dapat mengurangi terjadinya kerugian berinvestasi.

Investasi secara umum dapat dilakukan di dua tempat, yaitu pasar uang dan pasar modal. Investasi di pasar uang bersifat jangka pendek, yaitu instrumen investasi yang ditawarkan berjangka waktu kurang dari satu tahun. Sedangkan di pasar modal ditawarkan berbagai instrumen investasi berjangka panjang, antar lain: Saham yang merupakan surat tanda bukti kepemilikan atas suatu perusahaan, obligasi yang merupakan surat hutang jangka panjang yang diterbitkan oleh perusahaan dan pemerintah, dan derivatif yang merupakan produk turunan dari produk utamanya.

Setiap keputusan investasi akan ada tingkat risiko yang akan mempengaruhi nilai dari investasi tersebut. Hal ini berlaku juga untuk investasi pada aset keuangan berupa saham. Pada umumnya investasi yang memiliki tingkat pengembalian yang tinggi seperti saham akan dihadapkan pada suatu tingkat risiko yang tinggi pula, oleh sebab itu investor harus mampu untuk mengelola setiap risiko investasi yang timbul agar investasinya menjadi aman dan menguntungkan. Dari ketiga jenis instrumen investasi di atas, saham masih merupakan instrumen yang paling aktif diperdagangkan di Bursa Efek Indonesia.

Jenis risiko yang akan dibahas dalam penelitian ini adalah systematic risk. Risiko ini dipengaruhi oleh faktor fundamental ekonomi seperti suku bunga, inflasi, nilai tukar rupiah, maupun faktor nonfundamental ekonomi seperti politik. Penelitian ini akan menggunakan pergerakan harga saham sebagai faktor risiko yang timbul pada portofolio. Metode faktor risiko yang digunakan adalah Value at Risk.

Value at Risk pertama kali digunakan oleh perusahaan keuangan ternama pada akhir tahun 1980 untuk mengukur risiko portofolio transaksi mereka. Semenjak itu, penggunaan Value at Risk berkembang dengan sangat cepat.

Saat ini Value at Risk secara luas telah menjadi alat pengukuran risiko. VaR dapat menjawab seberapa besar kerugian investor dapat terjadi dengan probabilitas $\mathrm{X}$ $\%$ dalam waktu yang telah ditentukan.VaR mengukur jumlah risiko maksimum yang akan mereka terima (Jorion, 2007 : 244). Ada tiga metode yang umum digunakan untuk menentukan Value at Risk:

\section{Variance-Covariance (delta normal) VaR}

$$
\operatorname{VaR}=P z_{0,95} \sigma \sqrt{ } \mathrm{t} \text {. }
$$

Dimana:

P : Investasi dana awal

$\mathrm{z}_{0,95} \quad$ : Tingkat kepercayaan sebesar $95 \%$

$\sigma \quad$ : Volatilitas return aset tunggal

$\sqrt{t}_{\mathrm{t}} \quad:$ Periode waktu

\section{Monte Carlo Simulation VaR}

$$
\operatorname{VaR}=\mu-(\mathrm{Z} \times \sigma)
$$

Dimana:

VaR : Potensi kerugian maksimal

$\mu \quad$ : Besarnya nilai rata-rata return

Z : Tingkat Kepercayaan

$\sigma \quad$ : Standar Deviasi

\section{Historical simulation $\mathrm{VaR}$}

Dimana :

$$
\operatorname{VaR}_{(1-\alpha)}=\mu(R)-R \alpha .
$$

$\mathrm{VaR}_{(1-\alpha)}$ : potensi kerugian maksimal

$\mu(\mathrm{R})^{(1-\alpha)}$ : nilai rata-rata Return'

$\mathrm{R} \alpha \quad$ : rugi maksimum $\alpha$ tertentu

Arthini et al (2012) menganalisis perhitungan VaR portofolio saham mengunakan data historis dan data simulasi Monte Carlo pada empat perusahaan listing. Kesimpulanya nilai VaR dari simulasi Monte Carlo baik 
metode Exact maupun metode Expected lebih besar dari VaR data historis, ini disebabkan karena simulasi Monte Carlo melakukan iterasi yang berulang-ulang dengan mengikutsertakan pembangkitan bilangan acak. Nilai VaR dari data simulasi Monte Carlo dengan metode Exact lebih mendekati nilai VaR data historis karena nilai dari expected return dan standar deviasinya sama dengan data historis, sedangkan simulasi Monte Carlo dengan metode Expected distribusi statistiknya yang sama dengan data historis.

Terdapat juga penelitian oleh Leony, et al (2013) yang melakukan Pengukuran Value at Risk pada Aset Perusahaan dengan Metode Simulasi Monte Carlo. Kesimpulanya adalah Nilai VaR portofolio yang lebih rendah dari VaR aset tunggal disebabkan karena adanya efek diversifikasi.

Penelitian selanjutnya adalah penelitian yang dilakukan oleh Maruddani dan Purbowati (2009) bahwa daripada menggunakan nilai masa lalu faktor risiko, simulasi Monte Carlo menghasilkan model untuk memperkirakan faktor risiko dari masa lalu pengembalian portofolio dengan menentukan distribusi dan parameter mereka. Menggunakan distribusi ini dan parameter, kita bisa menghasilkan ribuan skenario hipotetis untuk faktor risiko dan, akhirnya, kita dapat menentukan harga di masa depan atau tarif berdasarkan skenario hipotetis.

Ben Rejeb et al (2012) menganalisis perhitungan VaR pada Tunisian Currency Market. Tujuan utama dari makalah ini adalah untuk membandingkan secara empiris empat Value at Risk dengan menggunakan metode Variance-Covariance, metode simulasi historis, Bootstraping, dan Monte Carlo. Penelitian ini mencoba untuk memperkirakan VaR terkait untuk tiga mata uang dan empat portofolio mata uang di pasar valuta Tunisia Secara independen dari teknik yang digunakan, Yen Jepang tampaknya menjadi mata uang yang paling berisiko. Selain itu, diversifikasi portofolio juga mengurangi risiko nilai tukar. Terakhir adalah jumlah valiations, secara umum tidak terlalu berbeda dari simulasi-simulasi yang digunakan. Belakangan ini tes evaluasi diterapkan untuk memilih teknik yang paling tepat memprediksi secara tepat risiko nilai tukar. Hasilya berdasarkan penelitian ini hasil tes menunjukkan bahwa tradisional Variance-Covariance adalah metode yang paling tepat untuk digunakan.

Terdapat juga penelitian Cakir et. al. (2013) yang melakukan analisis VaR. Kemudian, untuk setiap portofolio yang ditunjuk, metode simulasi MonteCarlo dijalankan untuk seribu kali untuk menghitung VaR. Akhirnya, penelitian ini menyimpulkan bahwa ada hubungan paralel antara risiko dihitung optimal portofolio dan nilai-nilai VaR portofolio.

Čorkalo (2011) meneliti perbandingan pendekatan
Value at Risk pada portofolio saham. Čorkalo melakukan perhitungan VaR dengan menggunakan metode variance covariace, simulasi historis dan Bootstraping. Hasilnya di bandingkan dalam bentuk grafik Histogram. Pada kesimpulan penelitianya tidak ada jawaban metode mana yang terbaik untuk digunakan. Para investor harus melihat komposisi dari portofolionya, selanjutnya baru memilih menggunakan metode apa. Akan sangat berguna jika menganalisis data historis untuk melihat distributions of return dan melihat pendekan mana yang dapat digunakan. Čorkalo menyarankan untuk mengindari penggunaan metode yang kompleks. Seperti yang ada pada penelitian ini, distributions of return tidak sepenuhnya normal. Jadi metode simulasi historis dan Bootstraping akan memberikan estimasi yang lebih baik.

Penulis memilih metode historis karena jurnal-jurnal terdahulu menyebutkan bahwa metode ini merupakan metode yang paling sederhana saat digunakan karena hanya menggunakan data historis dan mengesampingkan asumsi return yang berdistribusi normal maupun sifat linier antara return portofolio terhadap return aset tunggalnya.

Penulis memilih menggunakan simulasi Monte Carlo karena dalam Maruddani dan Purbowati (2009) menyatakan bahwa metode ini merupakan metode yang paling kuat untuk mengukur VaR karena dapat menghitung bermacam-macam susunan eksposur dan risiko meliputi risiko harga nonlinier, risiko volatilitas, dan risiko model tetap. Metode ini juga cukup fleksibel untuk menggabungkan variasi waktu pada volatilitas, fat tails dan skenario yang ekstrim. Simulasi dapat membangkitkan seluruh fungsi kepadatan peluang, tidak hanya satu kuantil dan dapat digunakan untuk menentukan ekspektasi kerugian yang melampaui nilai VaR.

Berdaskan metodenya peneliti melakukan jenis penelitian kuantitatif, karena dalam penelitian ini peneliti melakukan analisis perhitungan VaR yang datanya diperoleh dari www.finance.yahoo.com. Jenis penelitian yang digunakan penulis adalah deskriptif. Menurut Indrawati (2015:115) penelitian deskriptif biasanya dilakukan saat peneliti sudah mengetahui faktor atau variable untuk mengukur suatu objek atau bidang tetapi belum mengetahui hubungan antara faktor atau variabel tersebut. Penelitian ini mendeskripsikan pengukuran risiko dengan menggunakan metode historis dan metode Monte Carlo pada saham GGRM dan HMSP periode 1 September 2014 sampai 1 September 2016.

Berdasarkan waktu pelaksanaan, penelitian ini menggunakan Time Series, dengan data harian harga saham penutup GGRM dan HMSP pada periode 1 September 2014 sampai 1 September 2016. Pemilihan periode waktu tersebut dikarenakan munculnya 
Kebijakan pemerintah yang terus diperbaharui, keluarnya fatwa Majelis Ulama Indonesia (MUI) mengenai rokok, munculnya isu-isu rokok dan gencarnya kampanye anti rokok selama dua tahun terakhir menjadi tantangan besar industri rokok dan para investornya dalam mengelola risiko yang akan terjadi dimasa mendatang.

Pada penelitian ini menggunakan data sekunder perusahaan, yaitu data saham harian GGRM dan HMSP selama periode September 2014 sampai September 2016. Sumber data : www.finance.yahoo.com. Metode perthitungan metode simulasi historis, dan metode monte carlo.

Alasan pemilihan variabel return adalah karena perhitungan yang dibutuhkan dalam penelitian ini berpatokan pada nilai return dari harga penutupan pada objek yang diteliti.

Populasi dalam penelitian ini adalah perusahaan Sub Sektor Rokok yang tercatat di Bursa Efek Indonesia. Peneliti menggunakan teknik purposive sampling yang artinya pengembalian sampel berdasarkan pertimbangan yang ada, maka digunakan sampel harga saham GGRM dan HMSP dari tahun 2014 sampai dengan tahun 2016 dengan kriteria diantaranya; (1) Perusahaan yang diteliti adalah dua perusahaan terbaik berdasarkan aset pada sub sektor rokok dan terdaftar di BEI; (2) Perusahaan memiliki kelengkapan harga saham periode September 2014 sampai September 2016; (3) Perusahaan memiliki laporan keuangan yang sudah dipublikasi pada tahun 2014 sampai 2016. Data yang digunakan dalam penelitian ini adalah data harga saham harian GGRM dan HMSP. Periode penelitian dimulai dari 1 September 2014 sampai 1 September 2016, yang masing-masing perusahaan yang diteliti terdiri dari 514 data.

Teknik analisis data yang digunakan dalam penelitian ini adalah teknik analisis data kuantitatif. Hal pertama yang harus dilakukan adalah memperoleh data harga saham Gudang Garam dan HM Sampoerna pada 1 September 2014 sampai 1 September 2016. Software yang digunakan untuk membantu analisis data adalah Microsoft Excel.

Langkah-langkah untuk mengukur Value at Risk pada aset tunggal dengan metode Simulasi Historis adalah: (1) Menghitung return harian saham dengan menggunakan persamaan (1); (2) Mengurutkan data return dari nilai terkecil sampai dengan nilai terbesar; (3) Mencari Average Return dari data return; (4) Mencari estimasi kerugian maksimum pada tingkat kepercayaan (1- $\alpha$ ) tertentu; (5) Menghitung nilai VaR pada tingkat kepercayaan $(1-\alpha)$ tertentu dengan menggunakan persamaan (3).

Langkah-langkah untuk mengukur Value at Risk pada aset tunggal dengan metode simulasi Monte Carlo adalah: (1) Menghitung return harian saham dengan menggunakan persamaan (1); (2) Mencari Average Return dari data return; (3) Menghitung standar deviasi; (4) Melakukan simulasi Monte Carlo;
(5) Membuat simulasi sebanyak 1000 kali dengan menggunakan average return dan standar deviasi sebagai parameternya; (6) Menentukan rata-rata dan rugi minimum berdasarkan simulasi; (7) Menentukan Confidence Level (1- $\alpha)$ tertentu. Dalam penelitian ini Confidence Level yang digunakan adalah 95\%; (8) Mengitung nilai $\mathrm{VaR}$ dengan menggunakan persamaan (2).

\section{HASIL}

Data return dihitung karena volatilitas dipengaruhi oleh karakteristik dan return tersebut. Data return merupakan data time series yang berkesinambungan sehingga untuk mengetahui hasil return harian dapat dihitung berdasarkan price ratio. Deskripsi statistik dari saham GGRM dan HMSP dapat dilihat pada Tabel 2.

Tabel 2. Deskripsi statistik saham GGRM dan HMSP 1 September 2014 - 1 September 2016

\begin{tabular}{lcc}
\hline & GGRM & HMSP \\
\hline Average Return & 0,000473743 & 0,000966245 \\
Highest Return & 0,07580825 & 0,12179290 \\
Lowest Return & $-0,07888889$ & $-0,09701493$ \\
Standar deviasi & 0,021265139 & 0,019262613 \\
Observasi data return & 513 & 513 \\
\hline
\end{tabular}

Setelah data return diperoleh maka tahapan selanjutnya adalah melakukan perhitungan VaR dengan menggunakan metode historis dan Monte Carlo.

Hasil perhitungan VaR dengan menggunakan metode histroris ditunjukkan pada Tabel 3.

Tabel 3. Nilai VaR Simulasi Historis GGRM dan HMSP 1 September 2014 sampai 1 September 2016

\begin{tabular}{lcc}
\hline & GGRM & HMSP \\
\hline $\boldsymbol{\mu ( R )}$ & 0.0004737 & 0.0009662 \\
Standar deviation of return & 0.0212651 & 0.0192626 \\
Percentile & $5 \%$ & $5 \%$ \\
Ra & $-0,0323290$ & $-0,0248100$ \\
Confidence level & $95 \%$ & $95 \%$ \\
Nilai VaR & 0,0328027 & 0,0254078 \\
Nilai VaR (\%) & $3,28 \%$ & $2,54 \%$ \\
P (Dana Awal) & $\mathrm{Rp} 500,000,000$ & $\mathrm{Rp} 500,000,000$ \\
Nilai VaR & $\mathrm{Rp} 16.401 .371$ & $\mathrm{Rp} 12.888 .118$ \\
\hline
\end{tabular}

Perhitungan VaR dengan menggunakan metode Monte Carlo, nilai return aset yang berdistribusi normal disimulasikan dengan membangkitkan secara random nilai-nilai return acak dengan menggunakan parameter mean dan standar deviasi dari masing-masing return aset. 
Selanjutnya nilai VaR dengan mengunakan metode Monte Carlo dapat diperoleh. Hasil perhitungan VaR dengan menggunakan metode Monte Carlo ditunjukkan pada Tabel 4.

Tabel 4. Nilai perhitungan VaR Simulasi Monte Carlo GGRM dan HMSP 1 September 2014 sampai 1 September 2016

\begin{tabular}{lcc}
\hline & GGRM & HMSP \\
\hline Rata-rata Return $(\mu)$ & 0,000300197 & 0,000335850 \\
Standar deviasi $(\sigma)$ & 0,021596445 & 0,019286841 \\
Dana Investasi Awal & Rp500.000.000 & Rp500.000.000 \\
Z0,95 & 1,645 & 1,645 \\
Confidence level & $95 \%$ & $95 \%$ \\
Nilai VaR & $3,52 \%$ & $3,14 \%$ \\
Nilai VaR & Rp 17.612 .977 & $\mathrm{Rp} 15.695 .502$ \\
\hline
\end{tabular}

Setelah hasil perhitungan VaR diperoleh dengan menggunakan metode historis dan Monte Carlo, tahapan selanjutnya adalah membandingkan hasil VaR dari kedua metode perhitungan yang digunakan. Perbandingan nilai VaR dari kedua metode yang digunakan ditunjukkan pada Tabel 5.

Tabel 5. Hasil Perhitungan VaR

\begin{tabular}{lcc}
\hline & GGRM & HMSP \\
\hline Dana Awal & Rp500.000.000 & Rp500.000.000 \\
VaR Simulasi Historis (Rp) & $\mathrm{Rp} 16.401 .371$ & $\mathrm{Rp} 12.888 .118$ \\
VaR Simulasi Monte Carlo & $\mathrm{Rp} 17.612 .977$ & $\mathrm{Rp} 15.695 .502$ \\
$(\mathrm{Rp})$ & & \\
VaR Simulasi Historis (\%) & $3,28 \%$ & $2,54 \%$ \\
VaR Simulasi Monte Carlo & $3,52 \%$ & $3,14 \%$ \\
$(\%)$ & & \\
\hline
\end{tabular}

\section{PEMBAHASAN}

Rata-rata return GGRM periode 1 September 2014 sampai 1 September 2016 adalah 0,000473743 lebih rendah dibanding HMSP yang memiliki nilai 0,000966245 . Sama halnya pada return tertinggi, GGRM memiliki return lebih rendah dibandingkan HMSP. Observasi diamati pada 513 hari perdagangan. Tabel 2. juga menunjukkan terjadinya volatilitas yang signifikan dari kedua saham yang diteliti. Volatilitas dapat dilihat dari selisih nilai return tertinggi dan terendah yang terjadi. GGRM memiliki volatilitas -0,07888889 sampai 0,07580825, sedangkan untuk volatilitas HMSP adalah -0,09701493 sampai 0,12179290 atau dengan kata lain GGRM memiliki tingkat volatilitas lebih tinggi yang artinya tingkat fluktuasi pengembalianya lebih tinggi.

Nilai return aset yang telah dihitung datanya diurutkan dari nilai return yang terkecil hingga nilai return terbesar dan dihitung rata-rata returnmya. Selanjutnya adalah mencari estimasi kerugian maksimum pada tingkat kepercayaan $(1-\alpha)$ sebesar $95 \%$ dengan $\alpha$ sebesar $5 \%$ yaitu sebagai nilai kuantil ke- $\alpha$ dari distribusi empiris return yang diperoleh dengan bantuan fungsi $=$ percentile $($ array, $\mathrm{k})$ pada Microsoft Excel. Maka selanjutnya nilai VaR dapat diperoleh dengan menggunakan persamaan (1).

Penelitian ini tidak mengambil atau tidak merupakan studi kasus dalam sebuah perusahaan atau organisasi, maka penentuan exposure atau dana awal (P) adalah ditetapkan dengan keinginan peneliti sebesar limaratus juta dalam rupiah (Rp 500.000.000) hal ini dikarenakan dana investasi minimum untuk membuat portofolio adalah sebesar lima ratus juta rupiah.

Tabel 3. menunjukkan VaR aset GGRM sebesar Rp16.401.371, hal ini dapat diartikan ada keyakinan 95\% bahwa kerugian yang akan dialami investor tidak melebihi Rp16.401.371 dalam jangka waktu satu hari setelah periode data historis atau dapat dikatakan ada kemungkinan sebesar 5\% bahwa kerugian investasi pada saham GGRM sebesar Rp16.401.371 atau lebih.

VaR aset HMSP sebesar Rp12.888.118, hal ini dapat diartikan ada keyakinan $95 \%$ bahwa kerugian yang akan dialami investor tidak melebihi Rp12.888.118 dalam jangka waktu satu hari setelah periode data historis atau dapat dikatakan ada kemungkinan sebesar 5\% bahwa kerugian investasi pada saham HMSP sebesar Rp12.888.118 atau lebih.

Rata-rata return dan standar deviasi yang diperoleh dari data return GGRM dan HMSP dari 1 September 2014 sampai 1 September 2016. Nantinya nilai tersebut digunakan sebagai parameter untuk membangkitkan nilai return secara acak. Selanjutnya, dengan menggunakan rata-rata return dan standar deviasi sebagai parameter simulasi, maka simulasi untuk membangkitkan nilai return secara acak sebanyak 1000 kali dapat diperoleh dengan bantuan fungsi $=$ norminv $(\operatorname{rand}()$; mean; standard_dev) pada Microsoft Excel. Dimana fungsi $=$ rand() adalah angka acak yang lebih besar dari 0 dan lebih kecil dari 1.

Setelah simulasi dilakukan, maka rata-rata return dapat diperoleh dengan bantuan fungsi $=A V E R A G E($ number $1 ;$ [number 2$] ; \ldots$ ) dimana number 1 adalah simulasi return ke-1, number 2 simulasi return ke-2 dan seterusnya hingga simulasi ke-1000. Sedangkan standar deviasi dapat diperoleh dengan bantuan fungsi = STDEV (number1; [number2]; ...). Setelah nilai rata-rata return dan standar deviasi diperoleh, tingkat kepercayaan ditentukan yaitu 95\% $(1,645)$, maka selanjutnya VaR masing-masing aset dihitung dengan menggunakan persamaan (2).

Dapat dilihat pada Tabel 4. VaR aset GGRM dengan menggunakan simulasi Monte Carlo adalah sebesar 
Rp17.612.977, hal ini dapat diartikan ada keyakinan 95\% bahwa kerugian yang akan dialami investor tidak melebihi Rp17.612.977 dalam jangka waktu satu hari setelah periode data historis atau dapat dikatakan ada kemungkinan sebesar 5\% bahwa kerugian investasi pada saham GGRM sebesar Rp17.612.977 atau lebih.

VaR aset HMSP dengan menggunakan simulasi Monte Carlo adalah Rp15.695.502, hal ini dapat diartikan ada keyakinan $95 \%$ bahwa kerugian yang akan dialami investor tidak melebihi Rp15.695.502 dalam jangka waktu satu hari setelah periode data historis atau dapat dikatakan ada kemungkinan sebesar 5\% bahwa kerugian investasi pada saham HMSP sebesar Rp15.695.502 atau lebih.

Pada Tabel 5 dapat dilihat hasil perhitungan VaR dengan metode simulasi historis dan Monte Carlo dapat disimpulkan bahwa dari kedua perusahaan rokok yang diteliti periode 1 September 2014 sampai 1 September 2016 yang memiliki nilai risiko lebih besar adalah Gudang Garam dilihat dari nilai risiko pada kedua metode pengukuran VaR.

Hasil perhitungan juga menunjukkan simulasi Monte Carlo memberikan hasil yang lebih besar dibandingkan simulasi historis, hal ini dikarekan metode simulasi Monte Carlo melakukan iterasi yang berulang ulang dengan mengikutsertakan pembangkitan bilangan acak dan banyak mensintesiskan data sehingga sampel data menjadi lebih banyak yang membuat perhitungan semakin besar.

\section{KESIMPULAN}

Hasil perhitungan VaR menggunakan metode Historis dengan data 513 hari (1 September 2014 hingga 1 September 2016) menunjukkan nilai VaR sebesar 3,28\% untuk GGRM, sedangkan HMSP memiliki nilai VaR 2,54\%. Jika investor menginvestasikan dananya sebesar Rp 500.000.000,00 pada aset tunggal dengan tingkat kepercayaan 95\%, maka nilai risiko dari aset GGRM diperkirakan tidak akan melehihi Rp16.401.371, sedangkan VaR aset HMSP diperkirakan tidak akan melebihi Rp12.888.118.

Hasil perhitungan VaR menggunakan metode simulasi Monte Carlo dengan data 513 hari (1 September 2014 hingga 1 September 2016) menunjukkan nilai VaR sebesar 3,52\% untuk GGRM, sedangkan HMSP memiliki nilai VaR 3,14\%. Jika investor menginvestasikan dananya sebesar Rp 500.000.000,00 pada aset tunggal dengan tingkat kepercayaan 95\%, maka nilai risiko dari aset GGRM diperkirakan tidak akan melehihi Rp17.612.977, sedangkan VaR aset HMSP diperkirakan tidak akan melebihi Rp15.695.502.

Dari hasil perhitungan VaR dengan menggunakan kedua metode menunjukkan bahwa, simulasi Monte Carlo memberikan hasil yang lebih besar dibandingkan simulasi historis, hal ini dikarekan metode simulasi Monte Carlo melakukan iterasi yang berulang dengan mengikutsertakan pembangkitan bilangan acak dan banyak mensintesiskan data sehingga sampel data menjadi lebih banyak yang membuat perhitungan semakin besar.

\section{DAFTAR PUSTAKA}

Arthini, K Dharmawan, dan Harini. 2012. Perhitungan Var Portofolio Saham Menggunakan Data Historis Dan Data Simulasi Monte Carlo. e-Journal Matematika, Vol. 1, No. 1 Agustus 2012.

Ben Rejeb, A. 2012. Value-at-Risk Analysis for the Tunisian Currency Market. International Journal of Economics and Financial Issues, Vol. 2, No. 2.

Boddie Z., Kane A., Marcus A.J. 2014. Investment (Tenth ed.). USA: McGraw-Hill Education.

Brown and Reilly. 2011. Invesment Analisys and Portofolio Management (Tenth ed.). Canada: SouthWestern.

Cakir HM dan Uyar M. 2013. Portfolio Risk Management with Value at Risk: A Monte-Carlo Simulation on ISE-100. International Research Journal of Finance and Economics.

Čorkalo, S̆. 2011. Comparison Of Value At Risk Approaches On A Stock. Croatian Operational Research Review (CRORR), Vol. 2.

Damodaran, A. 2010. Value at Risk (VAR). USA: New York University.

Fahmi, I. 2012. Manajemen Investasi: Teori dan Soal Jawab. Jakarta: Salemba.

Indrawati. 2015. Metode Penelitian Manajemen dan Bisnis Konvergensi Teknologi Komunikasi dan Informasi. Bandung: Refika Aditama.

Jorion, P. 2007. Value at Risk The New Benchmarkfor Managing Financial (3rd ed.). USA: McGraw Hill.

Leony P, Manurung T, dan Prang JD. 2013. Pengukuran Value at Risk pada Aset Perusahaan dengan Metode Simulasi Monte Carlo . Jurnal Mipa Unsrat Online.

Maruddani dan Purbowati. 2009. Pengukuran Value at Risk pada Aset Tunggal dan Portofolio dengan Menggunakan Simulasi Monte Carlo (Studi Kasus PT. Telekomunikasi dan PT. Astra International). Media Statistika, Vol. II, No. 2.

Saham Oke. 2016. Sub Sektor Rokok di Bursa Efek Indonesia. Tersedia: http://www.sahamok.com/ emiten/sektor-industri-barang-konsumsi/sub\%09sektor-rokok/ [24 Desember 2016]

Setianto, B. 2011. Analisa Sub Sektor Rokok. Tersedia: https://books.google.co.id/books?id=J7tUCgAAQ $\mathrm{BAJ} \&$ printsec $=$ frontcov $\% 09 \mathrm{er} \mathrm{v}=$ onepage $\& \mathrm{q} \& \mathrm{f}=$ false[24 Desember 2016]

Tandelilin, E. 2010. Portofolio dan Investasi, Teori, dan Aplikasi (1st ed.). Yogyakarta: KANISIUS. 


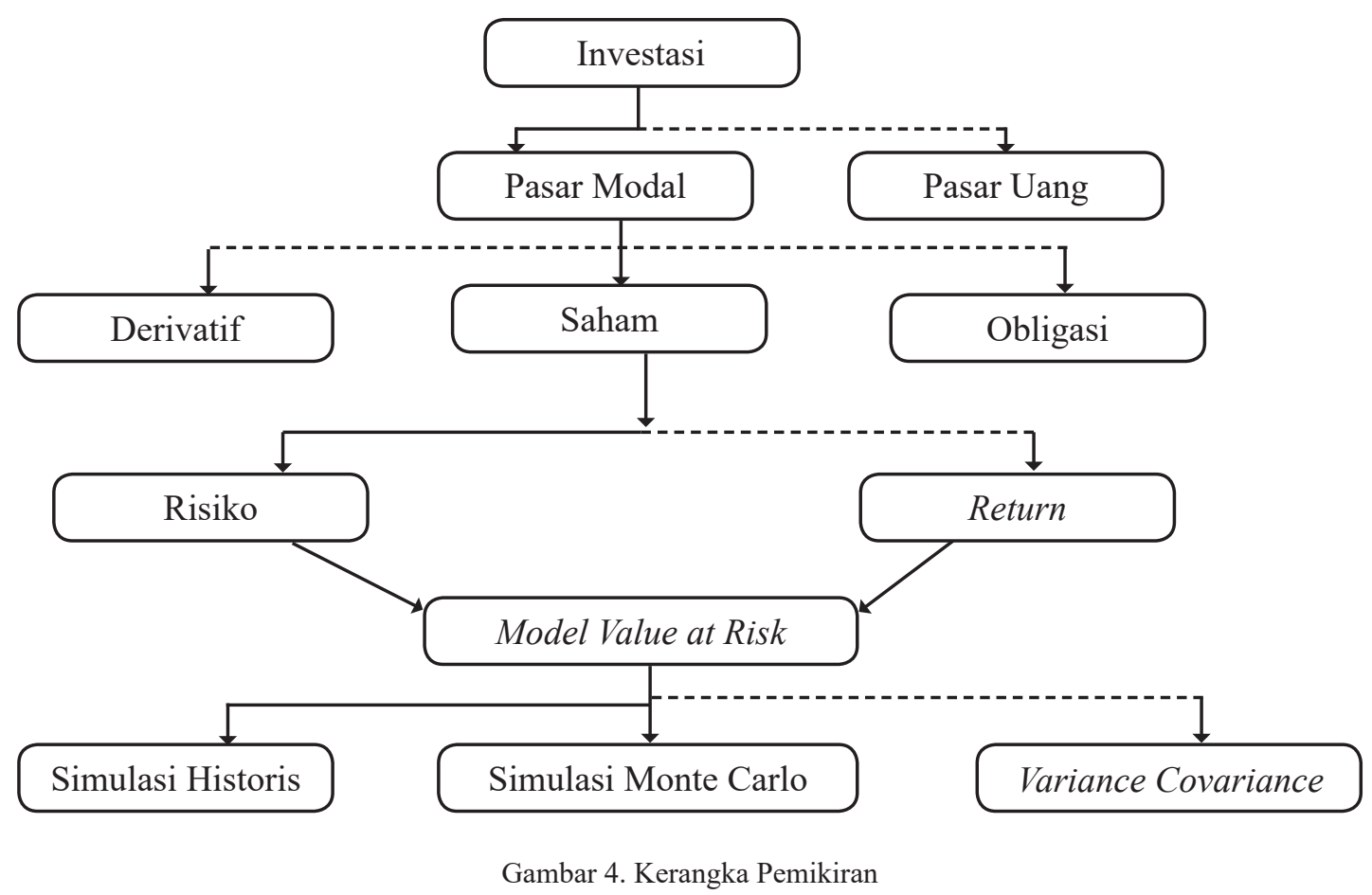

Keterangan:

$\longrightarrow$ Jalur Pemikiran yang diteliti

$\ldots+\ldots$ Jalur Pemikiran yang tidak diteliti 